\title{
Fire Impacts on the Mojave Desert Ecosystem: Literature Review
}

\author{
prepared by \\ Lynn Fenstermaker \\ Desert Research Institute \\ Nevada System of Higher Education \\ submitted to \\ U.S. Department of Energy \\ National Nuclear Security Administration \\ Nevada Site Office
}

January 2012

\section{Publication No. 45238}


Reference herein to any specific commercial product, process, or service by trade name, trademark, manufacturer, or otherwise, does not necessarily constitute or imply its endorsement, recommendation, or favoring by the United States Government or any agency thereof or its contractors or subcontractors. The views and opinions of authors expressed herein do not necessarily state or reflect those of the United States Government or any agency thereof.

This report has been reproduced directly from the best available copy.

Available for sale to the public, in paper, from:

U.S. Department of Commerce

National Technical Information Service

5301 Shawnee Road

Alexandria, VA 22312

phone: 800-553-6847

fax: 703-605-6900

email: orders@ntis.gov

online ordering: http://www.ntis.gov/help/ordermethods.aspx

Available electronically at http://www.doe.gov/bridge

Available for a processing fee to the U.S. Department of Energy and its contractors, in paper, from:

U.S. Department of Energy

Office of Scientific and Technical Information

P.O. Box 62

Oak Ridge, TN 37831-0062

phone: 423.576 .8401

fax: 423.576 .5728

email: reports@adonis.osti.gov 


\title{
Fire Impacts on the Mojave Desert Ecosystem: Literature Review
}

\author{
prepared by \\ Lynn Fenstermaker \\ Desert Research Institute \\ Nevada System of Higher Education
}

Publication No. 45238

submitted to

U.S. Department of Energy

National Nuclear Security Administration

Nevada Site Office

January 2012

The work upon which this report is based was supported by the U.S. Department of Energy under Contract \#s DE-AC52-06NA26383 and DE-NA0000939. Approved for public release; further dissemination unlimited. 
THIS PAGE LEFT INTENTIONALLY BLANK 


\section{CONTENTS}

List of Figures .......................................................................................................................... iii

List of Acronyms ................................................................................................................... iv

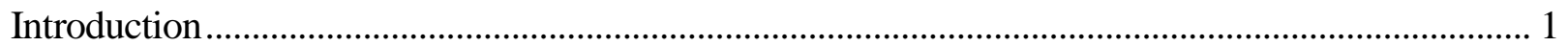

Soil Biological Chemical, and Physical Changes ………………………………………............. 2

Soil Biological Impacts: ........................................................................................ 3

Soil Chemical Impacts:_............................................................................................ 4

Soil Physical and Hydraulic Impacts:......................................................................... 7

Fire Impact on Hydrophobicity, Infiltration, Runoff and Water Erosion .............................................. 7

Fire Impact on Wind Erosion and Air Quality ……………………................................................. 10

Wind and Water Erosion of Radioactive Particles................................................................................. 13

Aridland Vegetation Change ........................................................................................................... 15

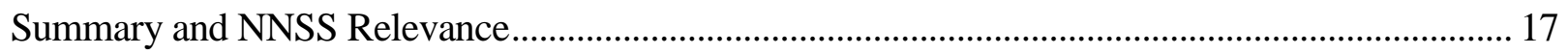

NNSS Soil and Plant Characteristics ......................................................................... 17

Potential NNSS Fire Impacts........................................................................................ 20

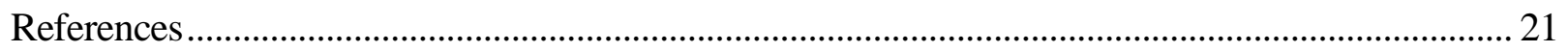

\section{LIST OF FIGURES}

1. Excerpted from Ryan, 2002: "Temperature ranges associated with various fire effects (top) (from Hungerford et al., 1991) compared to the depth of heat penetration into mineral soil (bottom) for a crown fire over exposed mineral soil (observed in jack pine Pinus banksiana in the Canadian Northwest Territories) or for ground fire burning in 515- and 25-cm of duff (predicted via Campbell et al., 1994, 1995)..................................... 3

2. Excerpted from Neary et al. (2008): "Sequence of rill formation on a burned slope with a water-repellent layer includes (A) saturation of wettable surface area, (B) development of a failure zone in wettable surface layer, (C) free flowing water over the water-repellent layer, (D) erosion of the water-repellent layer, (E) removal of the water repellent layer and infiltration into underlying wettable soil, and (F) resultant rill. (From Wells, 1987).

3. Distribution of Coleogyne ramosissima-Ephedra nevadensis shrubland on the NNSS;

Figure 4-12 from Ostler et al., 2000. 


\section{LIST OF ACRONYMS}

AZ

BSC

C

Ca

CAUs

$\mathrm{Ce}$

CEC

$\mathrm{Cl}$

$\mathrm{CO}$

DOE

$\mathrm{Fe}$

$\mathrm{ft}$

ha

IMPROVE

K

$\mathrm{m}$

$\mathrm{Mg}$

$\mathrm{Mn}$

$\mathrm{mm}$

$\mathrm{N}$

NM

NNSA

NNSS

NSO

NSTec

$\mathrm{OM}$

OR

$\mathrm{P}$

$\mathrm{Pu}$

RFETS

$\mathrm{S}$

U.S.

WA

WIPP

$\mathrm{Zn}$
Arizona

Biological Soil Crust

Carbon

Calcium

Corrective Action Units

Cesium

Cation Exchange Capacity

Chlorine

Colorado

Department of Energy

Iron

feet

hectare

Interagency Monitoring of Protected Visual Environments network

Potassium

meters

Magnesium

Manganese

millimeters

Nitrogen

New Mexico

National Nuclear Security Administration

Nevada National Security Site

Nevada Site Office

National Security Technologies, LLC

Organic Matter

Oregon

Phosphorus

Plutonium

Rocky Flats Environmental Technology Site

Sulfur

United States

Washington

Waste Isolation Pilot Plant

Zinc 


\section{INTRODUCTION}

The Nevada National Security Site (NNSS) is located within the Mojave Desert, which is the driest region in North America. Precipitation on the NNSS varies from an annual average of 130 millimeters (mm; 5.1 inches) with a minimum of $47 \mathrm{~mm}$ (1.9 inches) and maximum of 328 mm (12.9 inches) over the past 15 year period to an annual average of $205 \mathrm{~mm}$ (8.1 inches) with an annual minimum of $89 \mathrm{~mm}$ (3.5 inches) and maximum of $391 \mathrm{~mm}$ (15.4 inches) for the same time period; for a Frenchman Flat location at 970 meters (m; 3182 feet) and a Pahute Mesa location at $1986 \mathrm{~m}$ (6516 feet), respectively. The combination of aridity and temperature extremes has resulted in sparsely vegetated basins (desert shrub plant communities) to moderately vegetated mountains (mixed coniferous forest plant communities); both plant density and precipitation increase with increasing elevation. Whereas some plant communities have evolved under fire regimes and are dependent upon fire for seed germination, plant communities within the Mojave Desert are not dependent on a fire regime and therefore are highly impacted by fire (Brown and Minnich, 1986; Brooks, 1999). As noted by Johansen (2003) natural range fires are not prevalent in the Mojave and Sonoran Deserts because there is not enough vegetation present (too many shrub interspaces) to sustain a fire. Fire research and hence publications addressing fires in the Southwestern United States (U.S.) have therefore focused on forest, shrubsteppe and grassland fires caused by both natural and anthropogenic ignition sources. In the last few decades, however, invasion of mid-elevation shrublands by non-native Bromus madritensis ssp. rubens and Bromus tectorum (Hunter, 1991) have been highly correlated with increased fire frequency (Brooks and Berry, 2006; Brooks and Matchett, 2006). Coupled with the impact of climate change, which has already been shown to be playing a role in increased forest fires (Westerling et al., 2006), it is likely that the fire frequency will further increase in the Mojave Desert (Knapp 1998; Smith et al., 1987; Smith et al., 2000).

The increase in wildfires in arid and semi-arid parts of Nevada and elsewhere in the Southwest U.S. has implications for post-closure management and long-term stewardship for Soils Corrective Action Units (CAUs), areas of the NNSS for which the U.S. Department of Energy (DOE), National Nuclear Security Administration, Nevada Site Office (NNSA/NSO) has responsibility. For many CAUs and Corrective Action Sites, where closure-in-place alternatives are now being implemented or considered, there is a chance of wildfire at some point-in-time while radiation levels still pose a risk to the environment or human health, particularly given the long half-lives of some of the radionuclide contaminants of concern. Annual ecological monitoring and compliance program reports prepared by NNSA's onsite contractor staff (National Security Technologies, LLC -NSTec) predict NNSS wildfire hazards annually based on vegetation surveys; there were 106 survey locations in 2010. Hansen et al. (2011) have observed a positive correlation between winter precipitation and amount of vegetation biomass contributing to fuel loads. Over the past 33 years, the NNSS has had a total of 379 wildfires with an average of 11.5 wildfires per year burning an average of 81.2 hectare (ha; 200.6 acres) per year for a total of 30,814 ha (76,143 acres) burned (Hansen et al., 2011). Most of these fires occur in the summer months in blackbrush (Coleogyne ramosissima) communities (Hansen and Ostler, 2004) after most deciduous vegetation has senesced and there is a higher incidence of lightning due to monsoonal storms patterns.

Although NSTec staff has surveyed NNSS locations to predict potential wildfire on an annual basis and have documented colonization of burned areas by invasive grasses (e.g., Bromus madritensis ssp. rubens, Schismus arabicus and Bromus tectorum), studies of fire 
impacts on soil, erosion and overall changes in species composition have not been conducted to date. The goal of this report is to provide a better understanding of the potential impacts of wildfires on the NNSS with an emphasis on impacts to soil properties and resulting erosion based on published literature. The number of studies and publications specifically addressing the effect of fire in the Mojave Desert is quite limited. Whereas several Mojave Desert fire locations are being monitored to determine the effectiveness of multiple restoration techniques, a lack of funding has prohibited examination of the effect of fire on soil properties and erosion at these sites (L. DeFalco, U.S. Geological Survey personal communication). The following literature review summarizes fire effects in the Southwestern U.S. and, where possible, highlights the limited literature available on fire impacts to Mojave Desert ecosystems.

\section{SOIL BIOLOGICAL, CHEMICAL, AND PHYSICAL CHANGES}

As noted by several authors (DeBano et al., 1977; DeBano et al., 1998; Neary et al., 1999) changes in soil properties after a fire are dependent upon initial soil properties (particularly soil moisture), the plant community and the amount of soil heating, which is based upon the fire intensity and duration. Some low intensity fires are actually beneficial to the ecosystem through the release of nutrients that otherwise would not be available to plants (Neary et al., 1999). However, the more intense the fire, the higher the likelihood that harmful, longer term effects to soil and plant communities will occur. Examples of threshold temperature responses include (excerpted from p. 79 and Table 4.1 on p. 80 of DeBano et al., 1998; with original sources including: Hosking, 1938; Hare, 1961; DeBano and Krammes, 1966; Precht et al., 1973; White et al., 1973; Martin et al., 1975; Dunn and DeBano, 1977; Lyon et al., 1978; Dunn et al., 1985; Raison et al., 1985; Klopatek et al., 1988; DeBano, 1990, DeBano, 1991):

1) At temperatures approaching $100^{\circ} \mathrm{C}\left(212^{\circ} \mathrm{F}\right)$ death of biological organisms at the soil surface (biological soil crust - BSC) and within the top $5 \mathrm{~cm}$ (2 inches) of the soil profile occur. These organisms include bacteria, fungi, vesicular arbuscular mycorrhizae, plant roots, seeds and any insects or small mammals;

2) At temperatures of between 100 to $220^{\circ} \mathrm{C}\left(212\right.$ to $\left.392^{\circ} \mathrm{F}\right)$ soil water evaporates and soil dehydrates;

3) At temperatures between 220 and $460^{\circ} \mathrm{C}\left(428\right.$ and $\left.860^{\circ} \mathrm{F}\right)$ soil organic matter combusts and volatilization of sulfur $(\mathrm{S})$ and nitrogen $(\mathrm{N})$ occurs, which leads to hydrophobicity and a loss of soil structure; and,

4) At temperatures above $460^{\circ} \mathrm{C}\left(860^{\circ} \mathrm{F}\right)$ volatilization of manganese (Mn), calcium (Ca), magnesium $(\mathrm{Mg})$, phosphorus $(\mathrm{P})$ and potassium $(\mathrm{K})$ occurs and hydroxyl groups are driven off clay soil particles resulting in highly erodible soil.

Figure 1 presents the above information in graphic form with some slight differences in temperature thresholds due to differences in the literature. 

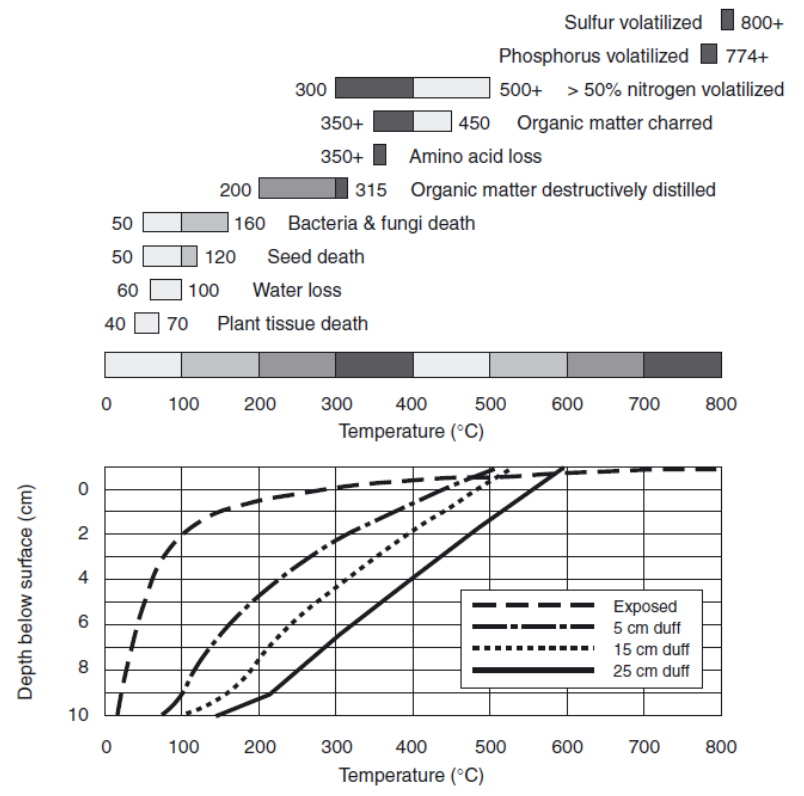

Figure 1. Excerpted from Ryan, 2002: “Temperature ranges associated with various fire effects (top) (from Hungerford et al., 1991) compared to the depth of heat penetration into mineral soil (bottom) for a crown fire over exposed mineral soil (observed in jack pine Pinus banksiana in the Canadian Northwest Territories) or for ground fire burning in 5-, 15- and 25-cm (2-, 6- and 10-inches) of duff (predicted via Campbell et al., 1994, 1995). Conditions are for coarse dry soil, which provides the best conduction (i.e., a worst-case scenario).”

\section{Soil Biological Impacts:}

Biological soil crusts (BSCs) are composed of cyanobacteria, lichen and mosses and are found at the soil surface in most arid and semi-arid environments where plant canopies are sparse (Belnap et al., 2003). These BSC play an important role in nutrient cycling, particularly $\mathrm{N}$ fixation, and also serve as a stabilizing agent that limits erosion as long as the surface remains intact. Fire impacts on BSC are not well documented for most ecosystems but are dependent upon the burn severity (e.g., temperature and duration) and other environmental factors (soil type, moisture content, species composition). However, it may be generally stated that fire typically results in decreased BSC cover, biomass and species diversity (Belnap and Eldredge, 2003), with hotter fires causing more damage and a slower recovery requiring decades to centuries in arid and semi-arid regions. Erickson and White (2008) summarized results from a Joint Fire Study Program post-fire monitoring effort by Stephen Hart and Gregory Newman that found functionally more diverse fungi but less diverse soil bacteria in the Santa Fe National Forest. This outcome was unanticipated as fungi are typically more sensitive to heat than bacteria.

A book chapter by Johansen (2003) describes the impact of fire on BSC in shrub-steppe ecosystems, the ecosystems with the most studies on fire impacts to BSC. The studies that were performed in the Great Basin revealed a significant decrease in algal (cyanobacteria) biomass, frequency and diatom density in burned areas versus adjacent unburned areas three years after the fire event occurred. Frequencies of two prevalent algal species in the burned area were on average one-quarter of those in the adjacent unburned area, although other algal species 
remained statistically unchanged at another study site at Dugway Proving Ground, Utah. Lichen cover was also significantly reduced (with only Collema tenax, a species of lichen similar to that found in the Mojave Desert, being the only lichen to survive) and bryophytes (mosses, liverworts and hornworts) were completely eliminated from the burned area. Compared to the unburned area, this translates to a loss of 13.5 percent soil cover by bryophytes. Even up to five years after the fire event, lichen cover was significantly less than in adjacent unburned areas and there was no bryophyte recovery (e.g., 0 percent cover), although algal community recovery (density and species richness and diversity) was observed.

In addition to fire-induced decreases in cyanobacteria and live diatom frequencies, a study in a big sagebrush (Artemesia tridentata) community in Eastern Washington revealed a suppression of the seasonal winter increase in chlorophyte density within the burned area. Johansen (2003) notes that the only study to take place in a Creosote (Larrea tridentata) plant community, New Mexico (NM), revealed patchy fire effects. The most intensely burned areas had significantly less filamentous cyanobacteria and lichen cover in comparison to either lightly or unburned areas (e.g., 40.5 to 4.4 percent for cyanobacteria and 23.2 to 0.8 percent for lichen cover), although other algae revealed no statistical difference between burned and unburned areas. Unfortunately the algal species that tend to survive fire appear to be unimportant to overall ecosystem function.

The impact of fire-induced changes in BSC, described above, result in decreased $\mathrm{N}$ fixation. In addition, the lack of BSC cover on the soil surface results in a significant decrease in infiltration and increases in runoff and sedimentation (Johansen, 2003). The patchy nature of fire in the Mojave Desert bodes well for the recovery of BSC as islands of lightly burned areas can serve as sources for colonization of adjacent burned areas (Johansen, 2003). In two Great Basin studies, full recovery of BSC photosynthetic biomass (e.g., algal biomass) recovered in five years, although an unusually wet winter preceeded the year of full recovery. Therefore, environmental conditions likely play a bigger role in recovery than the period of time since the fire event. Bryophytes, followed by lichens, are the next to recover in timeframes of 4-7 years and 13-35 years, respectively, for a Eucalyptus site (Eldridge and Bradstock, 1994). However, some blackbrush (Coleogyne ramosissima) sites were observed to have no recovery even 37 years post fire (Callison et al., 1985).

Soil mycorrhizae (fungi symbiotically colonized on plant roots) are significantly impacted by fire (reduction in species richness and spore count; Klopatek et al., 1993) and there is a concurrent loss of fine plant root biomass (Erickson and White, 2008). The reduction in both mycorrhizae and fine roots are likely to impact seedling survival, particularly for plants that are dependent upon mycorrhizal associations to acquire nutrients for growth.

In summary, fire impacts on soil biological components are significant and have the combined effect of: 1 ) reducing the availability of important plant nutrients through reduced infiltration and loss of $\mathrm{N}$ fixation; 2) increasing soil erosion due to the loss of BSC that serves as a soil surface stabilization agent; and 3) requiring decades or longer to approach pre-fire frequencies, densities and species richness. All of these effects may be significant fire impacts to Mojave Desert soils, but have not been studied to date.

\section{Soil Chemical Impacts:}

Soil chemical elements and compounds typically affected by fire include a number of critical plant nutrients, i.e., organic matter (OM), N, carbon (C), P, S, cation exchange capacity 
(CEC) and pH (Knoepp et al., 2005). Knoepp et al. (2005) point out important considerations when examining data describing impacts of fire on chemical elements. The first consideration is whether the change is reported as a total amount or percentage of a particular element. Pre and post fire samples are fundamentally different (e.g., pre-fire samples have a variable amount of $\mathrm{OM}$ and post fire samples contain ash as well as unburned $\mathrm{OM}$ ). The second consideration is that fire never increases the total amounts of chemical elements, but it is common to see a decrease in the total amount of certain elements. Fire does however change the chemical form of some elements often making them more available for plant uptake; for example, fire will decrease the total $\mathrm{N}$ content at a site, but the amount of plant available $\mathrm{N}$ will increase.

The impact of fire on litter and OM sitting at the soil surface and within the top soil horizon has received considerable attention due to the important role they play in nutrient cycling. The amount of litter and OM at the surface of Mojave Desert soils varies from patchy small amounts under isolated shrubs in the valleys to moderate amounts in forested mountainous areas (DeBano et al., 1998). Despite the limited amount of litter and OM in the Mojave, it is worthwhile to discuss the impact of fire on OM because even at low amounts OM provides nutrients to an otherwise nutrient-limited desert soil as well as significant changes in soil properties post fire such as a loss of soil structure (Welling et al., 1984; DeBano et al., 1998). At temperatures below the thresholds mentioned in the Introduction, elements ( $\mathrm{P}, \mathrm{Mn}, \mathrm{K}, \mathrm{Ca}$ and $\mathrm{Mg}$ ) may be found as insoluble oxides in the residual fire ash. However, these oxides will react with rain water and carbon dioxide $\left(\mathrm{CO}_{2}\right)$ in air to form salts that can be leached into and through the soil profile (Welling et al., 1984) resulting in a potential temporary increase in cation availability and soil pH (National Wildlife Coordinating Group, 2001). However, DeBano and Conrad (1978) found that soil pH decreased from 7.01 to 6.83 within the top $1 \mathrm{~cm}$ (0.4 inches) of a chaparral soil post fire indicating that fires may produce either a slight increase or decrease in soil $\mathrm{pH}$. Because $\mathrm{pH}$ affects availability of certain cations, fire induced changes in $\mathrm{pH}$ may increase or decrease nutrient availability depending on the direction and amount of change in $\mathrm{pH}$. Other soluble nutrients are also leached from the soil during post-fire precipitation events, placing a limit on the time that any remaining or newly germinated plants may benefit from the release of nutrients when OM is burned. At high temperatures (severe fires), nutrients are typically volatilized and lost to the atmosphere; Neary et al. (1999) report that over half of the $\mathrm{N}$ in OM may be lost through volatilization.

Heating of the soil and burning of OM also impacts the CEC of the soil. The CEC is a term used to describe the sum of cations that both the OM and inorganic soil colloids hold in the soil via negatively charged surfaces. During typical range fires, soils are heated to a point where the OM and humic materials are destroyed. Whereas clay particles are not typically altered (see section on soil physical impacts), the destruction of OM and humic materials in the soil surface results in a lower CEC and thus less cations (nutrients) are available for seedling establishment post fire (Neary et al., 2008).

Examination of soil inorganic $\mathrm{N}$ after experimental fires in a Mojave Desert shrubland (Larrea tridentata, Ambrosia dumosa plant community) revealed a significant increase in ammonium $\left(\mathrm{NH}_{4}{ }^{+}\right)$and a statistically insignificant increase in nitrate $\left(\mathrm{NO}_{3}{ }^{-}\right)$, particularly under Ambrosia and Larrea canopy locations (Esque et al., 2010). These elevated levels of $\mathrm{N}$ declined over a 172 day period post-fire, but still remained higher in burned sites compared to paired unburned sites. Laboratory dry and wet incubations of burned and unburned soil revealed the 
following differences in net ammonification ${ }^{1}$ and nitrification ${ }^{2}$ rates: 1 ) dry soils (ambient soil moisture levels) had net ammonification rates near zero but were significantly greater than the ammonification rate for a wet soil treatment; 2) burning did not significantly alter dry net ammonification and rates became less negative over time; 3) experimental wetting of soil yielded higher net ammonification in interspaces versus under canopies and also yielded higher values for unburned (positive or near zero values) versus burned soils (negative values), which became significantly less negative over time; 4) the dry (ambient) soil treatment had near zero net nitrification rates with no difference between burned and unburned sites; 5) wet treatment soil nitrification rates were higher than the values for the dry treatment with no difference between burned and unburned soils; and 6) net nitrification was higher in the under-canopy locations in comparison to interspaces and declined over time (Esque et al., 2010). The results of this study indicate that combined increase in post-fire ammonia with enhanced nitrification following a post-fire precipitation event are likely to produce more plant available $\mathrm{N}$ for seedling establishment, particularly in under-canopy locations.

Studies by Blank et al. $(1994,1996)$ examined the effect of wildfire on soils of an Artemesia tridentata (sagebrush) plant community. Although this plant community is within the Great Basin Desert (cooler and moister than the Mojave Desert), the plant density and existence of shrub interspaces is similar to the Mojave. This study was unique because it examined both the temporal and spatial variability of organic and inorganic anions in post-fire sagebrush soils. The authors found that differences in anions were restricted to the surface soil $(0-5 \mathrm{~cm} ; 0-2$ inches) and only in "under canopy" locations immediately after the fire. No significant differences were found between burned and unburned "under canopy" one year after the fire and for interspace surface soils immediately after the fire and one year post-fire. Nitrates (KClextractable $\mathrm{NO}^{3-}$ ) were significantly decreased post fire, whereas sulfates (KCl-extractable $\mathrm{SO}_{4}{ }^{2-}$ ) and organic anions and organic acids increased after fire. The high level of organic acids might favorably affect seed germination and seedling establishment post fire. The authors also hypothesized that the increased amount of organic anions in "under canopy" locations might be due to the higher fire temperature at these locations rather than the increased fuel load of the shrub.

In general, fires typically increase the amount of available nutrients immediately post-fire in locales where either enhanced fuel loads (OM) and higher fire temperatures were present. Conflicting results have been found for $\mathrm{N}$ levels with Blank et al. (1994) reporting an $\mathrm{N}$ decline post-fire in arid/semi-arid shrubland areas and Esque et al. (2010) reporting a pulse of $\mathrm{N}$ post-fire in a Mojave Desert shrubland experimental fire. Over time and with leaching via precipitation, nutrient levels decline as the time interval since the fire increases resulting in lower nutrient levels than pre-fire conditions (Welling et al., 1984; DeBano et al., 1998; and National Wildlife Coordinating Group, 2001). In arid and semi-arid regions, changes in soil nutrients tend to be restricted to the top $5 \mathrm{~cm}$ (2 inches) of the surface soil due to low fuel loads and not only vary over time but also have a high degree of spatial heterogeneity directly related to canopy and interspace locations (Blank et al., 1994, 1996).

\footnotetext{
${ }^{1}$ Ammonification or mineralization is the process whereby organic $\mathrm{N}$ is converted to ammonia

${ }^{2}$ Nitrification is the conversion of ammonia to nitrate, which is more readily absorbed by plants
} 


\section{Soil Physical and Hydraulic Impacts:}

Physical impacts from fire are often the result of an indirect effect from a loss of OM and soil chemical alteration; these impacts include changes in soil structure, porosity, bulk density and aggregation (DeBano, 1991). These physical factors are inter-related, i.e., soil structure and aggregation create macropore channels that increase infiltration as does porosity, which is the volume of soil pores within a volume of soil. Bulk density is integrally related to porosity as it is a measure of the mass of mineral soil matter within a volume of soil, and thus bulk density decreases with increasing porosity (Neary et al., 2008). Until all soil moisture is evaporated, soil temperatures will not exceed $100^{\circ} \mathrm{C}\left(212^{\circ} \mathrm{F}\right.$; DeBano et al., 1976). As soil heating increases, after removal of soil water, significant effects on soil physical properties may occur (Welling et al., 1984). Whereas temperatures above $400^{\circ} \mathrm{C}\left(752^{\circ} \mathrm{F}\right)$ have been found to increase the percentage of silt and sand size particles (Welling et al., 1984), other studies (DeBano and Conrad, 1978) have found no significant change in soil particle size fractions after a prescribed fire (where temperatures are generally lower than for wildfires), indicating that fire temperatures, duration and local conditions probably play an important role in any potential changes to soil texture. Hungerford et al. (1991) also note that most fires do not cause sufficient soil heating to alter soil structure; however, Neary et al. (2008) state that soil structure resulting from OM (humus) acting as an aggregating "glue” is negatively impacted by soil surface heating as a result of fire. When soil structure is destroyed by soil heating, the porosity is decreased (and hence bulk density increases) in the surface soil (DeBano et al., 1998).

The amount of soil heating during a fire is a combined result of depth of litter layers, amount of OM and water in the surface soil, and soil porosity. The more litter and OM present, the longer a fire will burn resulting in vaporization of soil water and increased soil heating (DeBano et al., 1998; Neary et al., 2008).The primary impact of collective changes in soil physical variables as a result of soil heating is a reduction of infiltration and movement of OM deeper into the soil (approximately 4-5 cm; 1.6-2.0 inches), which results in increased water repellency or hydrophobicity (Neary et al., 2008). An examination of soil physical properties following prescribed fires within a Chaparral ecosystem revealed a mosaic of impacts related to the burning of specific plant species and litter present on the surface (Hubbert et al., 2006). These authors noted an overall loss in the pre-existing weak soil structure, a decrease in litter and clay content, an increase in bulk density and a resulting increase in water repellency seven days after the fire. However, the change in water repellency was short-lived and by 76 days after the fire water repellency was nearing pre-fire values except in site specific locations related to specific shrub species.

Although there are essentially no published studies on the impacts of fire on Mojave Desert soils, the low amounts of litter and OM in these soils would indicate the likelihood of limited, heterogeneous impacts on soil physical factors. As noted by DeBano et al. (1979), destruction of soil structure via soil heating has not been found to occur in all studies.

\section{FIRE IMPACT ON HYDROPHOBICITY, INFILTRATION, RUNOFF AND WATER EROSION}

It is well documented that post-fire landscapes are prone to increased precipitation runoff and sediment flow (Neary et al., 2008). One of the primary reasons for increased runoff is the enhancement of hydrophobicity (water repellency) due to the burning and volatilization of OM as noted in the previous section. A portion of the volatilized OM is leached by post-fire 
precipitation down into the top $5 \mathrm{~cm}$ (2 inches) of the soil surface to form a water-repellant layer that significantly limits the amount of water than can infiltrate into the soil profile (DeBano, 1991), although Hubbert et al. (2006) found increased water repellency without post-fire precipitation. Hubbert et al. (2006) thought that the increased hydrophobicity found at their site was likely due to increased soil drying and soil temperature changes that intensified the naturally occurring water repellency. In a review of hydrophobicity DeBano (2000) states that hydrophobicity is caused by soil OM and is present in both burned and unburned soil. There are five factors that influence water repellency in soils, which are quoted here from Neary et al. (2008) page 38:

1) An irreversible drying of the OM (for example, rewetting dried peat).

2) The coating of mineral soil particles with leachates from organic materials (for example, coarse-grained materials treated with plant extracts).

3) The coating of soil particles with hydrophobic microbial byproducts (for example, fungal mycelium).

4) The intermixing of dry mineral soil particles and dry OM.

5) The vaporization of OM and condensation of hydrophobic substances on mineral soil particles during fire (for example, heat-induced water repellency).

The degree to which hydrophobicity is enhanced by fire is dependent upon a number of factors including: severity of fire and resulting soil temperature gradients-the more severe the fire and resulting steep gradients in soil temperature increase the downward movement of volatilized OM into the soil surface (typically 4-5 cm; 1.6-2.0 inches); the type and amount of OM present; and the texture and water content of the soil, coarse textured soils appear to be more susceptible to enhanced hydrophobicity caused by fire. DeBano (2000) cites research that revealed a temperature relationship with the intensity of hydrophobicity following a fire. At temperatures below $175^{\circ} \mathrm{C}\left(347^{\circ} \mathrm{F}\right)$ there is little change in water repellency between burned and unburned areas. The most intense increase in hydrophobicity occurs when surface soils are heated to temperatures between 175 and $200^{\circ} \mathrm{C}\left(347\right.$ and $392^{\circ} \mathrm{F}$ ), and at temperatures between 280 and $400^{\circ} \mathrm{C}\left(536\right.$ and $752^{\circ} \mathrm{F}$ ) hydrophobicity is destroyed.

Hydrophobicity has a significant impact on infiltration rates and hence runoff from burned sites. DeBano (1976) found that the presence of a water repellant layer at or near the soil surface resulted in slower infiltration rates, particularly at the initiation of infiltration. However, as more precipitation falls on soil that has already been moistened, infiltration rates will increase (Neary et al., 2008). When rain falls on a hydrophobic soil, soil particles that resist wetting are displaced by the energy of the rain droplets striking the surface. After a fire, the hydrophobic soil layer is typically found below the soil surface $(4-5 \mathrm{~cm}$; 1.6-2.0 inches), which allows the soil surface to saturate with eventual creation of a "failure zone" above the hydrophobic zone, and turbulent movement of water downslope along this zone results in the movement of soil particles and the formation of rills - small channels (Gabet, 2003). Figure 2 depicts the initial process of rill formation and erosion caused by fire enhanced hydrophobicity. The amount of erosion that occurs is a function of surface cover (amount of vegetation present), soil particle size and transport velocity, which is dependent on the slope of the area and amount and intensity of precipitation or wind (Neary et al., 2008). During precipitation events, erosion may occur as sheets, rills or gullies. Sheet erosion is the uniform movement of water and soil particles across a surface. As this process continues, rill erosion develops as linear rectangular areas that are less resistant to erosion erode faster than adjacent areas. During extreme precipitation events or 
subsequent precipitation events rills grow into larger, deeper channels called gullies. As these channels become larger more sediment is transported downslope and eventually deposited in flat, lower slope areas (Neary et al., 2008). Erosion response after wildfire is therefore considered to include three processes: detachment transport and deposition of soil particles (Moody et al., 2008).

The amount of post-fire erosion is dependent upon the local topography, soil parent material and amount of time after the fire before a major precipitation event. If there is sufficient time for seedling re-establishment, then major storm events will result in less erosion
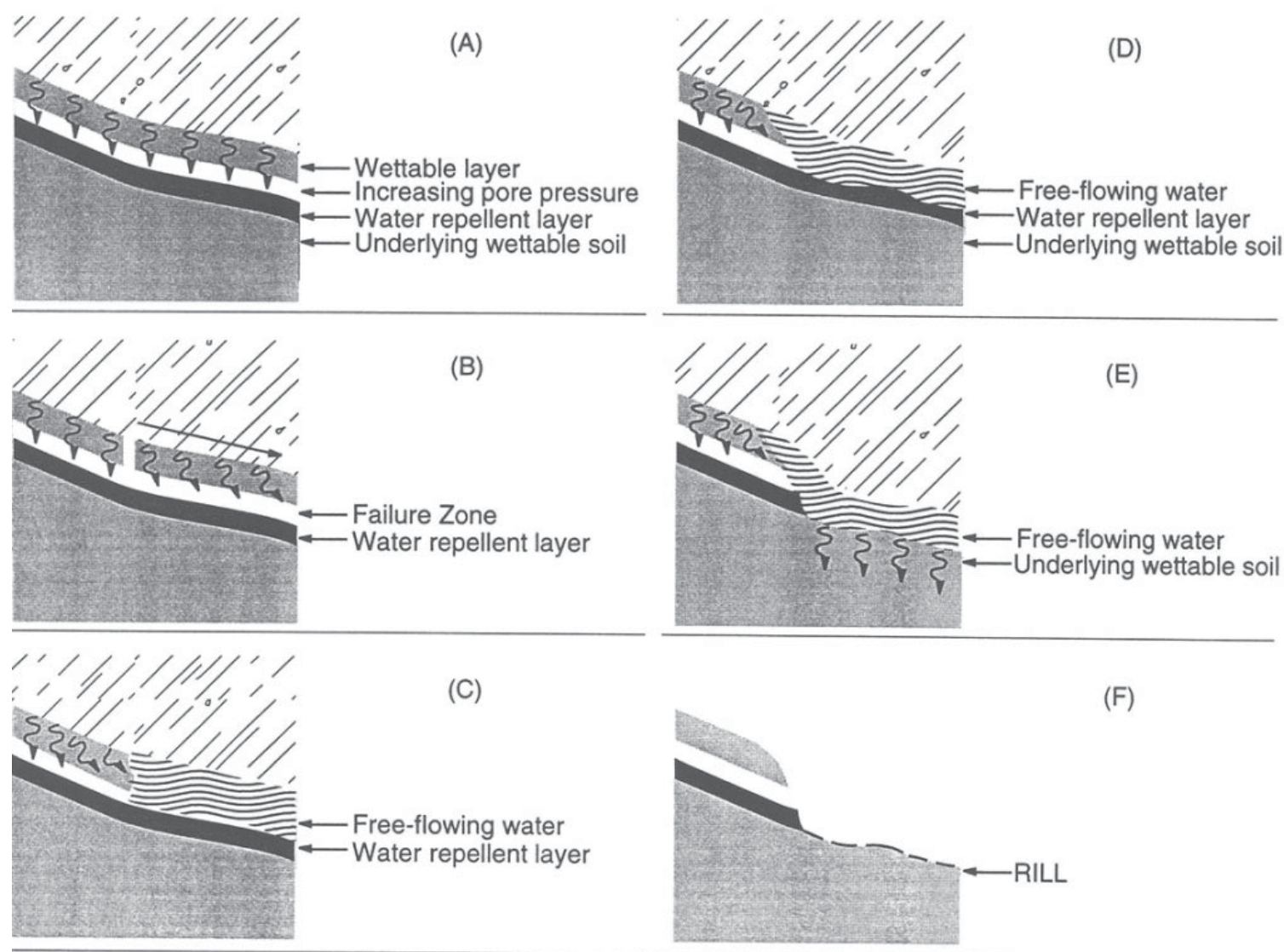

Figure 2. Excerpted from Neary et al. (2008): "Sequence of rill formation on a burned slope with a water-repellent layer includes (A) saturation of wettable surface area, (B) development of a failure zone in wettable surface layer, (C) free flowing water over the water-repellent layer, (D) erosion of the water-repellent layer, (E) removal of the water repellent layer and infiltration into underlying wettable soil, and (F) resultant rill. (From Wells,1987). The effects of fire on the generation of debris flows in southern California. Reviews in Engineering Geology. 7:105-114. Modified with permission of the publisher, the Geological Society of America, Boulder, Colorado U.S.A. Copyright (C) 1987 Geological Society of America.)” 
(Moody et al., 2008). The most extreme case of post-fire erosion is a hyperconcentrated flow, which only occur on steep slopes when a significant rain event occurs before plants can re-establish after a fire. Sediment yields from mass debris flows can range from 1,910 m3 km-2 year-1 (4,845 yard3/mile2/year) to 89,953 m3 km-2 (304,761 yard3/mile2; Neary et al., 2008). These types of flows are typically considered to be a direct result of fireenhanced water repellency when the mass of saturated soil sediments exceeds the sheer strength required to hold that mass in place.

A study of wildfire impacts on sagebrush-steppe soil hydrological properties by Pierson et al. (2002) examined the effect of aspect in addition to slope on erosion. Although the presence and severity of fire had no impact on the initiation of runoff, there was a significant decrease in infiltration rates and hence significant increases in the sediment-runoff ration for burned southfacing slopes in comparison to comparable north-facing slopes. This may be a result of the higher vegetation cover and vegetation-induced greater micro-topography on north-facing slopes prior to fire, indicating the important role of vegetation cover type and density on post-fire erosion.

Robichaud et al. (2006, 2007a, 2007b) have developed an internet-based model that allows users to predict potential soil erosion based on the probability of a rain event, post-fire soil properties and soil surface burn severity. The model is named ERMiT (Erosion Risk Management Tool). The information required for this web-based model includes: selection of a climate (based on available monthly PRISM data describing mean maximum and minimum temperature, mean precipitation and number of wet days); soil texture and percent rock content; vegetation type (forest, range or chaparral); hillslope gradient and horizontal length; and soil burn severity class. The resulting output describes rainfall event rankings, a probability graph of sediment erosion delivery and a comparison of mitigation treatment effects on sediment delivery.

In summary, the effect of fire on enhancement of hydrophobicity, decreased infiltration and resulting increased runoff and erosion are well documented for several western U.S. ecosystems. The most pronounced effects, e.g., most significant erosion, occurs on steep slopes when significant precipitation events occur before seedling re-establishment after a fire event. Sites on south-facing slopes or areas where pre-fire vegetation density is sparser experience more erosion than comparable north-facing slopes or areas of denser vegetation cover. Although the literature reviewed for this section did not include the Mojave Desert ecosystems, some assumptions can be made about fire impacts on soil erosion in the Mojave. Increased hydrophobicity will likely occur in a spatially heterogeneous nature related to the location of shrubs and trees within the landscape. The increased hydrophobicity will reduce infiltration and hence increase runoff and the potential for soil erosion. The amount of soil erosion will be dependent upon slope, intensity of precipitation and soil properties.

\section{FIRE IMPACT ON WIND EROSION AND AIR QUALITY}

Most of the literature examined focuses on wind suspension of particulate matter in general and is not specifically related to post-fire wind erosion. A number of articles discuss fire products that are dispersed to the atmosphere, but these primarily focus on the constituents found in smoke while the fire is burning. The criteria air pollutants (National Ambient Air Quality Standards developed by the U.S. Environmental Protection Agency) found in wildfire smoke include particulates, $\mathrm{CO}_{2}$, sulfur dioxide, nitrogen dioxide and ozone (DeBano et al., 1998). According to DeBano et al. (1998) $\mathrm{CO}_{2}$ is the single largest emission during a fire and comprises 
up to 90 percent of fire emissions. The remaining $C$ constituents emitted during a fire include carbon monoxide (CO) at 10 percent and approximately 1 percent each for methane, nonmethane hydrocarbons and particulate OM. The second largest emission is water vapor. Other constituents that are released in fire smoke include: aldehydes and polynuclear aromatic hydrocarbons (both of which are considered to be harmful to human health); $\mathrm{N}$ and S oxides; free radicals; and ash (DeBano et al., 1998). Although the amount of particulate matter released during a fire is small in comparison to other constituents such as $\mathrm{CO}_{2}$, it can have a significant impact on visibility and human health by aggravating respiratory conditions (DeBano et al., 1998). According to the Environmental Protection Agency, suspended particles smaller than $10 \mu \mathrm{m}$ (PM10) are capable of entering human lungs and thus can cause or increase harmful respiratory conditions. One of the earliest studies to measure particulate sizes found that spherical particles approximately 0.1 $\mu \mathrm{m}$ in diameter were most prevalent in smoke from smoldering fuel beds composed of Douglas fir slash (Sandberg and Martin, 1975). The second most prevalent particle was a roughly spherical agglomeration of the smaller $0.1 \mu \mathrm{m}$ particles that vary in diameter up to $80 \mu \mathrm{m}$. The other particulates observed included some solid, angular particles ranging in diameter from 0.05 to $20 \mu \mathrm{m}$.

The amount of smoke emitted during a fire is dependent on a number of factors including fire intensity, type and amount of OM, moisture status, topography and weather conditions. DeBano et al. (1998) cited research showing higher amounts of smoke from fire burning in steep terrain in comparison to flat terrain and a significant increase in smoke from fires during the fall season (lower moisture status) in comparison to fires during the spring in Oregon (OR) and Washington (WA). A study on the interannual variations in PM2.5 (2.5 $\mu \mathrm{m}$ particulate matter) resulting from wildfires in the western U.S. was published by Jaffe et al. (2008). As an interesting side note, Jaffe et al. (2008) subdivided the western U.S. into five subregions with the exception of Nevada and southern California, which were excluded from the analysis. For two of the regions studied (Central and Northern Rocky Mountains), a significant correlation was found between PM2.5 levels ${ }^{3}$ and two fire factors (fire area and biomass burned). In the Pacific Northwest region, as well as the Rocky Mountain regions, a good correlation was found between seasonal mean PM2.5 concentrations among the sites. The central California (CA) and Southwest (i.e., Arizona/New Mexico -AZ/NM) regions were not as strongly correlated likely due to anthropogenic emissions in CA and smoke drift from the Rocky Mountains south into the Southwest region. The average summer increase in PM2.5 concentrations as a result of wildfire ranged between 0.61 (Southwest region; AZ/NM) and $1.84 \mu \mathrm{g} \mathrm{m}^{-3}$ (Northern Rocky Mountains).

Another study conducted by Park et al. (2007) estimated biomass burning contributions to seasonal and annual aerosol concentrations using data from the Interagency Monitoring of Protected Visual Environments network (IMPROVE). Non-soil K levels were used as a tracer for biomass burning. They found that total carbonaceous particulates were the highest (up to $5.2 \mu \mathrm{g} \mathrm{C} \mathrm{m}^{-3}$ at an OR site and exceeding $1 \mu \mathrm{g} \mathrm{C} \mathrm{m}^{-3}$ in southwestern states) and most variable during summer months, when wildfires are prevalent.

An examination of the chemical constituents of PM2.5 emitted during a prescribed forest fire near Flagstaff, AZ, was studied by Robinson et al. (2004). Chemical constituents varied

\footnotetext{
${ }^{3}$ Measured by the Interagency Monitoring of Protected Visual Environments (IMPROVE) network, a consortium of federal land management agencies established by the U.S. Environmental Protection Agency in 1985.
} 
depending on whether the fire was flaming or smoldering. PM2.5 particles were primarily composed of organic compounds, particularly the $C$ fractions. The fire flame stage produced the highest particle concentrations, particularly ammonium and nitrate ions. During the smoldering phase total particulate and nitrate levels decreased but ammoniums levels remained elevated. Other elements detected in both the flaming and smoldering phases included Silicon, S, Chlorine (Cl), K, Ca, bromine, iron (Fe), zinc ( $\mathrm{Zn}$ ) and lead. Detectable levels of Titanium and Chromium were also found. Grassland fires that were also examined as a part of this study revealed lower particulate concentrations with 92 percent of the elemental mass comprised of $\mathrm{K}, \mathrm{Cl}, \mathrm{S}$ and $\mathrm{Ca}$, trace amounts of Fe and $\mathrm{Zn}$, but low levels of nitrates and no detectable ammonium.

The previously discussed studies focused on emissions released during wild and prescribed fires. They do not provide specific information on post-fire wind erosion of soil and ash particulates. Information reported in publications examining the IMPROVE data can be used to infer soil particulate erosion, but it is difficult to determine the proportion of suspended particulates originating from wind erosion of previously burned areas versus unburned areas. The southwestern U.S. is noted for having the highest concentrations of fine particulate soil matter, seasonal OM and light absorbing $\mathrm{C}$ (related to biomass burning seasonality), approximately double that of other U.S. regions (Maim et al., 2004; Hand et al., 2011). The suspension of particulate soil matter is likely due to wind erosion of surface soils in this sparsely vegetated region. However, the design and spatial resolution of the IMPROVE network does not provide a means to estimate differences in particulate emission from undisturbed/unburned versus disturbed/burned sites.

Only a few studies have examined the effect of fire on soil wind erosion in a semiarid environment. A study by Whicker et al. (2002) assessed the spatial heterogeneity of wind erosion rates for a Chihuahuan desert shrubland on a weekly timescale for comparable burned and unburned sites. The authors measured aerosol mass, number concentrations and particle size (using passive collectors), in addition to components of wind erosion (friction velocities and aerodynamic roughness lengths) as well as site characteristics (e.g., surface soil particle size distribution and plant parameters) and basic micrometeorological data (e.g., wind speed). There was a significant difference in the amount of aerosol particulates collected at the burned site ( 0.2 to $14.7 \mathrm{~g} \mathrm{~d}^{-1}$, median $=0.3 \mathrm{~g} \mathrm{~d}^{-1}$ ) versus the unburned site ( 0.01 to $1.8 \mathrm{~g} \mathrm{~d}^{-1}$, median $=0.1 \mathrm{~g} \mathrm{~d}^{-1}$ ). Immediately following the fire (summer months) the particulate collection rate was 70 times higher for the burned site in comparison to the unburned site and throughout the entire study period (3 months) the burned site collection rate was 3 times higher than that of the unburned site. To determine whether the suspension of soil particles resulted in net soil erosion, the authors measured changes in microtopography at $5 \mathrm{~cm}$ (2 inch) intervals along an approximate $2 \mathrm{~m}$ level bar immediately after installation and 162 days later. The mean change in surface topography at the burned site was significantly larger $(-5.8 \mathrm{~mm} ;-0.23$ inch) than that of the unburned site $(+1.9 \mathrm{~mm}$ or +0.07 inches; an addition of soil at the surface). There was a significantly greater loss of soil at the burned site in the under canopy areas (a mean of approximately $-9 \mathrm{~mm}$; 0.35 inch) in comparison to the interspace areas (a mean of approximately $-3 \mathrm{~mm} ; 0.12 \mathrm{inch}$ ). The authors concluded that the amount of wind erosion was most closely related to the mean of the daily peak gust speed, which was consistent with the threshold wind velocity of approximately $7 \mathrm{~m} \mathrm{~s}^{-1}$ (15.7 miles per hour), and that the burned site had soil erosion loss from both the under canopy and interspace locations, whereas the unburned site experienced soil deposition in the under canopy locations. 
The second study summarized herein is a study for a semiarid grassland performed by Ravi et al. (2009). This study focused on the effect of fire-enhanced hydrophobicity on wind erodibility of soil particles and was performed in a laboratory setting using wind tunnels. Both field and laboratory tests confirmed that the burned soil had enhanced hydrophobicity, although the laboratory measurements produced different results, i.e., in the field the water-drop penetration time was 5-10 minutes, whereas in the lab, the penetration time was reduced to 2-5 minutes. This may indicate an alteration of soil properties via disturbance during sampling. Unburned soils had no delay in water-drop penetration as water drops were instantly absorbed. Prior to wind tunnel testing, burned and unburned soil samples were passed through a $2 \mathrm{~mm}$ sieve and were allowed to equilibrate to ambient humidity; thus both burned and unburned samples were reported to have similar soil moisture contents. The wind tunnel tests revealed that the threshold friction velocity for burned soils was significantly less than that for unburned soils indicating a great susceptibility to wind erosion. A similar wind tunnel study by Ravi et al. (2006) has also shown an increased susceptibility of burned soils to wind erosion.

In summary, research has shown a significant increase in the emission of fine particulates (particularly carbonaceous particulates) as a result of wild fires, particularly during summer months in the southwestern U.S. and that these emissions can have a large temporal and spatial effect depending on the size and intensity of the fire (Maim et al., 2004; Park et al., 2007). Fire effects on soils, particularly hydrophobicity, produces a significant decrease in the threshold shear velocity for wind erosion thereby increasing the susceptibility of burned soils to wind erosion (Ravi et al., 2009). The amount of wind erosion is related to wind speeds (peak gusts) and varies spatially with the location of pre-fire canopies versus interspaces (Whicker et al., 2002).

\section{WIND AND WATER EROSION OF RADIOACTIVE PARTICLES}

One of the earliest peer-review publications discussing the erodibility of plutonium contaminated soils was Anspaugh et al. (1975). These authors defined the processes of winddriven particle movement, e.g., suspension, saltation and surface creep ${ }^{4}$ and then discussed models to predict plutonium resuspension rates. They developed a resuspension rate of $2.7 \times 10^{-12} \mathrm{sec}^{-1}$ to $4.8 \times 10^{-10} \mathrm{sec}^{-1}$, which were considered to be consistent with the time since nuclear tests occurred $(20 \mathrm{yr})$ that resulted in the deposition of these particles. These authors also found that the resuspension rate was highly correlated with the friction velocity ${ }^{5}$ while saltation was occurring. A national meeting abstract (Johnson et al., 2000) mentions the use of standard equations to estimate transport of low level contaminants at DOE semiarid sites. These models included RUSLE for water erosion, RWEQ for wind erosion and RESRAD for downward migration within the soil profile. The two disadvantages of RUSLE, RWEQ and RESRAD are

\footnotetext{
${ }^{4}$ Suspension is airborne movement of particles less than $100 \mu \mathrm{m}$ that have settling velocities less than the turbulent eddy velocities that caused these particles to be airborne; saltation is the airborne movement of particles generally ranging in size from 50-500 $\mu \mathrm{m}$, e.g., small enough to be moved by surface wind but large enough to have settling velocities greater than the upward eddy velocity; and surface creep is the rolling of particles along the soil surface that are too large (but still less than 2 $\mathrm{mm}$ ) to become airborne.

${ }^{5}$ Friction velocity is a measure of the surface stress resulting from the effect of surface roughness and wind velocity, where surface stress is the vertical flux of momentum near the surface as the ambient (horizontal) wind interacts with the surface (http://www.arm.gov/measurements).
} 
that they were designed to estimate long-term averages at coarse spatial resolutions. Results and conclusions from the modeling efforts were not mentioned within the single paragraph abstract other than a statement that there were significant differences in the rate of contaminant transport via wind, water and downward migration among the DOE sites (i.e., Los Alamos, Rocky Flats, Waste Isolation Pilot Plant -WIPP, NNSS, Hanford, Idaho and Pantex).

A study examining the suspension of plutonium from the Rocky Flats nuclear plant in Colorado (CO) and the Hanford Reservation in WA measured airborne plutonium concentrations as a function of particle diameter and wind speed (Sehmel, 1978). The maximum respirable concentration of plutonium $\left({ }^{239} \mathrm{Pu}\right.$ ) at Rocky Flats (3 measurement sites within a 227 m distance) was $7 \times 10^{-3} \mu \mathrm{Ci} \mathrm{g}^{-1}$ with a general decrease in Pu concentration with increasing distance from the original storage area. It was noted that there were some significant standard deviations (numbers not provided) in the measurements with both distance and height. The authors thought these might be due to the sampling of some $\mathrm{Pu}$ particles that had a higher activity. The ratio of airborne to soil surface ${ }^{239} \mathrm{Pu}$ particles was 0.04 to $0.2 \mu \mathrm{Ci} \mathrm{g}{ }^{-1}$ at one Rocky Flats site and 0.0001 to $0.08 \mu \mathrm{Ci} \mathrm{g}^{-1}$ at another Rocky Flats sampling site. The maximum amount of ${ }^{239} \mathrm{Pu}$ in airborne and soil surface samples from the Hanford reservation was $6 \times 10^{-5} \mu \mathrm{Ci} \mathrm{g}^{-1}$ and $8 \times 10^{-9} \mu \mathrm{Ci} \mathrm{g}^{-1}$, respectively, with a ratio of airborne to soil surface of $8 \times 10^{3}$. Although there were several orders of magnitude of uncertainty in the relationship between airborne and soil surface ${ }^{239} \mathrm{Pu}$ concentrations, all airborne ${ }^{239} \mathrm{Pu}$ concentrations were significantly below the maximum permissible air concentrations.

A study that examined the resuspension of radionuclides during both a natural and experimental forest fire was carried out within the fallout zone greater than $30 \mathrm{~km}$ (18.6 miles) from Chernobyl (Kashparov et al., 2000). The forest site was primarily contaminated with Cesium $\left({ }^{137} \mathrm{Cs}\right)$ by the condensed component of radioactive fallout at $1.1 \pm 0.2 \mathrm{MBq} \mathrm{m}^{-2}$. A dry grass site was also assessed and this site had initial levels of ${ }^{137} \mathrm{Cs}$ activity within the grass of 3.7 $\pm 0.8 \mathrm{kBq} \mathrm{kg}^{-1}$ and the background airborne concentration was $3 \mathrm{mBq} \mathrm{m}{ }^{-3}$. Measurements of the airborne radioactive concentration were measured during the fire experiment and the maximum concentration occurred while the fire was flaming, $10-100 \mathrm{mBq} \mathrm{m}^{-3}$. During the smoldering phase the concentration dropped to $5-20 \mathrm{mBq} \mathrm{m}^{-3}$ and one day after the fire the concentration further dropped to $2-5 \mathrm{mBq} \mathrm{m}^{-3}$. The authors state that: "The resuspension factors observed in the present study are close to those obtained for Chernobyl radioactive aerosols in 1986-1987 in Austria, Germany, Poland, Italy, Finland, Denmark, Norway and UK.” The authors also found that the respirable concentration of ${ }^{137} \mathrm{Cs}$ during the active and smoldering fire phases increased 20-700 times and post fire 3-30 times the natural background levels. The airborne integral concentration of ${ }^{137} \mathrm{Cs}$ was found to extend beyond 20,000 $\mathrm{m}$ from the site of the forest fire at values from greater than $500 \mathrm{~Bq} \mathrm{~s} \mathrm{~m}^{-3}$ near the fire to $150 \mathrm{~Bq} \mathrm{~s} \mathrm{~m}^{-3}$ at $20,000 \mathrm{~m}$. These data were then used to estimate dose rates via inhalation for firefighters during a 1 hour stay within the fire area. The inhalation exposures were $1.06 \times 10^{-9} \mathrm{~Sv}, 0.32 \times 10^{-9} \mathrm{~Sv}$ and $2.13 \times 10^{-9} \mathrm{~Sv}$ for deposition zones 1-3, respectively (i.e., 0-10 m, 10-110 m and greater than $110 \mathrm{~m}$; 0-33 feet, 33361 feet and greater than 361 feet). However, external irradiation accounted for 99 percent of the total doses at a dose of $1.5 \times 10-6 \mathrm{~Sv}$ for each of the three zones. The authors concluded that “...radionuclide resuspension during forest fires will not provide a significant contribution to terrestrial contamination” for contaminated regions greater than $30 \mathrm{~km}$ (18.6 miles) from Chernobyl. Within this same zone the inhalation dose to total does will not exceed several percent; however, at sites within the $30 \mathrm{~km}$ (18.6 miles) region around Chernobyl, the presence of alpha radionuclides could exceed external exposure doses. 
The only study that examined the impact of fire on hydrologic transport of radionuclides was a study performed at the WIPP, near Carlsbad, NM, and the Rocky Flats Environmental Technology Site (RFETS), CO (Johansen et al., 2001). A controlled grass fire and rainfall simulations were performed to assess rainfall transport of surface soil particles and the concentration of ${ }^{137} \mathrm{Cs}$ was measured. The results showed that runoff occurred earlier and with greater amounts at the burned plots in comparison to the unburned plots at WIPP. The time until runoff occurred at RFETS burned and unburned plots was similar, but the amount of increased runoff at RFETS was smaller than that at WIPP due to differences in soil texture (more silt and clay at RFETS whereas WIPP had 91 percent sand). Transport of ${ }^{137} \mathrm{Cs}$ was 22 times higher for the burned WIPP plots in comparison to the unburned plots and was 4 times higher for the burned RFETS plots. The authors also found that enrichment ratios (the increase in ${ }^{137} \mathrm{Cs}$ concentration in transported sediments versus original surface soil concentration) of water transported sediment (both burned and unburned plots) was 2.6 and 2.1 at WIPP and 1.4 and 1.2 at RFETS, burned and unburned plots, respectively. These results therefore indicate that runoff from burned contaminated areas will yield significantly more sediment transport with a higher concentration of radionuclides and that the amount of contaminated sediment transport is dependent on soil texture properties. Although it was noted that the percentage of ${ }^{137} \mathrm{Cs}$ lost from the original surface soil via runoff was less than 0.1 percent after simulations of a large storm event, potential for large increases of radionuclide runoff transport was stated.

In summary, wildfires increase both wind and water erosion of sediment-sorbed contaminates, depending on the original soil texture composition. The sparse nature of vegetation in arid and semi-arid environments results in spatial heterogeneity of fire-induced erosion rates and volumes.

\section{ARIDLAND VEGETATION CHANGE}

As mentioned in the introduction, fires have been infrequent in the Mojave Desert until the recent invasion by Bromus madritensis, ssp. rubens, red brome, and Bromus tectorum, cheat grass (Brooks and Berry, 2006; Brooks and Matchett, 2006). In the 1980s, changes in Larrea tridentata (creosote bush) communities were reported as the result of fire (Rogers and Steele, 1980; Brown and Minnich, 1986). Brown and Minnich, (1986) reported that although Larrea tridentata shrubs survived the fire with scorching of the stems, only Encelia farinosa (Brittlebush) showed a significant increase in seedling densities in burned versus unburned sites. This study also reported a significant increase in percent cover by the invasive Bromus madritensis, ssp. rubens and Schismus barbatus (Mediterranean grass) in comparison to native species in burned locations.

Similar observations were made in a comparison between burned and unburned Coleogyne ramosissima (Blackbrush) communities within three Mojave Desert locations (Brooks and Matchett, 2003). The focus of this study was to examine the impact of fire on species diversity. Three study sites where fire had previously occurred (7-14 years previous) were selected within Blackbrush communities that spanned the Mojave Desert (UT, NV and CA). Paired burned and unburned plots were established at each location and the canopy cover of each species present was determined. Species richness decreased as a result of burning although there was an increase in non-native species at burned sites. In unburned sites the average plant cover was 49 percent with Coleogyne as the dominant species. Although the total canopy cover at burned sites was similar (50 percent), Coleogyne was almost completely removed by fire resulting in a 60 percent lower cover by woody species in the burned sites compared to the 
unburned sites. Therefore, the burned sites were dominated by annual and perennial forb and grass cover (a 266 percent increase at one burned site compared to the paired unburned site). Non-native species cover was increased by 191 percent whereas native species cover declined in burned sites.

A study that examined the effect of post-fire recovery time among comparable Coleogyne communites in UT revealed that even after 37 years post-fire, Coleogyne showed no signs of recovery (Callison et al., 1985). This study further reported that forbs dominated more recently burned sites, grasses dominated median age sites and shrubs dominated the oldest burn sites. In all cases, it was noted that the BSC were severely impacted by fire and showed no evidence of recovery 20 years post-fire.

Joshua tree (Yucca brevifolia) is often found within Coleogyne plant communities of the Mojave Desert. Joshua trees are long-lived species and previously have been found to resprout after fire and disturbance (Loik et al., 2000). However, coupled with drought a recent study found that fire significantly decreased the probability of Yucca brevifolia survival whether the individual trees had been damaged directly by fire or not (DeFalco et al., 2010) and this decline was significantly more than the decline in survivability for a comparable unburned site. Results such as this indicate the likelihood of enhanced fire impacts under predicted future climate change where temperatures will increase and precipitation will become more variable with the likelihood of an overall slight decline in total precipitation (Seager et al., 2007).

A study by Brooks (2002) examined the effect of fire temperature variability on Mojave Desert annuals. As anticipated peak fire temperatures were found beneath Larrea tridentata shrubs (mean peak temperatures of 87 and $135^{\circ} \mathrm{C}\left(189\right.$ and $\left.275^{\circ} \mathrm{F}\right)$ respectively at 2 and $0 \mathrm{~cm}(0.8$ and 0 inches) soil depth during a spring fire) and interspaces experienced the lowest temperatures not exceeding $40^{\circ} \mathrm{C}\left(104^{\circ} \mathrm{F}\right)$. Fires occurring during the summer had higher beneath canopy temperatures, reaching up to $250^{\circ} \mathrm{C}\left(482^{\circ} \mathrm{F}\right)$ at $5-10 \mathrm{~cm}$ (2-4 inches) above the soil surface. Annual species response to fire varied by annual type, microhabitat and post-fire year. Annuals from burned under-canopy locations had reduced biomass for all four study years compared to the unburned microhabitat likely due to high temperature impacts on seed mortality. However, no differences were found between burned and unburned plots for annual biomass from interspace locations. The results of this study indicate that fire temperatures and annual biomass are both significantly higher in locations where pre-fire canopy cover is the greatest and hence annual response to fire will vary spatially by microhabitat.

A review of post-fire recovery literature for the Mojave and Sonoran Deserts was performed by Abella (2009). Only 14 publications were found that discussed post-fire recovery compared to unburned sites and provided quantitative data on resprouting or plant community composition, seven publications each within the Mojave and Sonoran Deserts (a subset of which were discussed above). In general, the percentage of Mojave Desert shrubs species resprouting after fire was small, e.g., Larrea tridentata resprouting varied from 3 to 38 percent, although Yucca schidigera had resprouting percentages of 64 and 86 percent in the two publications reporting results for this species. Another trend discovered was the overall low resprouting of Cactaceae and low growing shrubs with compact crowns such as Ambrosia and Encelia farinosa. All studies showed an increase in plant cover over time (within 10 percent or the same as unburned sites by 40 years post-fire); however, species composition varied between burned and unburned sites even after a significant period of time. The inability of these sites to return to 
previous species compositions over time indicates a likely continued divergence in species composition with time between burned and unburned sites.

Although vegetation response to fire has been found to vary by species, microhabitat and time since fire in the Mojave Desert, some general conclusions can be made from reported studies. First, only a few species are more resistant to fire than others (e.g., high Yucca schidigera resprouting rates) with most plant species showing a decrease in resprouting. Annual and perennial forb species tend to be the first to occupy newly burned areas followed by grasses, which may be predominantly composed of invasives, and finally by woody species. However, whereas plant canopy cover eventually returns to levels similar to unburned sites, it appears that some sites will never regain a species composition similar to pre-fire conditions. This alteration of species composition may have significant impacts on ecosystem function, fire re-occurrence and habitat for native animals.

\section{SUMMARY AND NNSS RELEVANCE}

Examination of the literature has shown that although the types of fire impacts in the southwestern U.S. are often very similar, the amount or severity of these impacts varies as a result of fire intensity and duration, pre-fire vegetation community composition and density, soil properties and topography (DeBano et al., 1977; DeBano et al., 1998; Neary et al., 1999). In addition to partial or total elimination of vegetation and surface OM, fire impacts soil biological, chemical and physical properties, which in turn lead to an enhanced potential for water and wind erosion. As noted by several authors (Knapp 1998; Smith et al., 1987; Hunter, 1991; Smith et al., 2000; Hansen and Ostler, 2004; Brooks and Berry, 2006; Brooks and Matchett, 2006) climate change and increases in invasive species, such as Bromus tectorum and Bromus madritensis ssp. rubens, has led to more frequent wildfires in the Mojave Desert, including the NNSS. The following sections highlight soil and plant characteristics of the NNSS and potential wildland fire impacts based on these characteristics.

\section{NNSS Soil and Plant Characteristics}

Mojave Desert soils have spatially heterogeneous biological and chemical properties with nutrient “islands" associated with shrub locations (Schlesinger et al., 1996). Biological soil crusts have been visually identified for approximately 40-50 percent of the NNSS area with BSC cover decreasing with increasing elevation (Ostler et al., 2000), however, laboratory determination of cyanobacteria absence or presence was not performed. BSC were monitored on a southern Frenchman Flat bajada of the NNSS (Belnap et al., 2007) with moss and lichen percent cover ranging from 13 percent to almost 20 percent. Lichen and moss BSC are not found under the canopy of Larrea tridentata, but are associated with other Mojave Desert shrubs and bunchgrasses such as Lycium and Pleuraphis rigida as well as canopy interspaces (observations by L. Stark, University of Nevada, Las Vegas and L. Fenstermaker, DRI). Lichen and moss cover did not vary significantly with rainfall until after a severe drought during late 2006 and spring 2007, which caused a significant decline in lichen and moss cover. Cyanobacteria BSC are found throughout desert soils including this NNSS location. The amount of cyanobacteria occurring at the site were found to be highly and positively correlated ( $\mathrm{r} 2=0.93$ ) with the amount of precipitation occurring six months prior to sample dates. Belnap et al. (2007) found both spatial and temporal variability in BSC cover and biomass.

Soil chemical properties were assessed for this same site by Titus et al. (2002) who found that the soils were generally nutrient poor, but had higher concentrations of $\mathrm{N}, \mathrm{P}, \mathrm{Mg}$ and 
sodium, more litter and OM, and a higher $\mathrm{pH}$ and CEC in shrub canopy locations in comparison to canopy interspaces. The larger the shrub size the greater the $\mathrm{N}, \mathrm{P}$ and $\mathrm{K}$ concentrations, which was likely a result of the increased litter and OM under the larger shrubs. The authors also found that nutrient content varied by shrub species with soils under Lycium shrubs having the highest $\mathrm{pH}$ and CEC. Generally, the interspace soils were finer textured than under canopy soils, which tended to a higher sand concentration than the interspaces. The coarser textured soils also had higher infiltration rates. These authors also noted that nutrient levels are likely to be temporally heterogeneous as well as spatially heterogeneous.

The NNSS landscape is typical of the southwest basin and range province with unvegetated playas occupying the lowest elevations, shrubland bajadas at the mid-elevations and forested mountains and mesas at the upper elevations. The NNSS is located at the transition between the northern Mojave and Great Basin Deserts, which is evident in the vegetation communities on the NNSS as well as the climate conditions. Vegetation mapping of the NNSS has been performed most recently by Ostler et al. (2000) using satellite remote sensing, aerial photography, landform analysis, topography and field data for 1508 of the ecological landform units derived from image and geographic information system analysis. These authors identified three regions of the NNSS. In the northern Great Basin Desert region, the Artemisia tridentataChrysothamnus viscidiflorus shrubland plant community had the largest percent cover of all plant communities identified. In the southern Mojave Desert region, the Larrea tridentata Ambrosia dumosa shrubland plant community had the largest percent cover. Plants from both deserts were identified in the central Transition region with the Coleogyne ramosissmaEphedra nevadensis shrubland plant community identified as having the largest cover area. It is this Coleogyne ramosissma - Ephedra nevadensis shrubland plant community that has been identified by Hansen and Ostler (2004) as the NNSS plant community with the highest incidence of wildland fire. The map depicting the location of this plant community (Figure 3) may therefore be viewed as a high risk area for future wildland fire depending on climate conditions and senesced plant biomass present on the surface.

The key impacts of fire on the NNSS are the loss of vegetation, particularly blackbrush (Coleogyne ramosissima) and the enhancement of erosion processes due to a loss of vegetative cover, long-term loss of BSC (particularly lichen and moss), and enhancement of hydrophobicity (Pierson et al., 2002; Johansen 2003; DeBano 1976). The potential for increased erosion (water and wind) on burned sites that have radionuclide contamination is of particular concern if contaminant transport occurs and produces an increased risk for human exposure. Increased erosion potentials are linked to increased hydrophobicity from fire. The enhancement of a hydrophobic layer decreases infiltration at approximately 4-5 cm (1.6-2.0 inches) soil depth and thereby increases runoff during precipitation events and the loss of saturated soil particles above the water repellent layer (Neary et al., 2008). Because the development of a hydrophobic layer is dependent on the presence of OM, fire-induced hydrophobicity on the NNSS will be patchy and will correspond to the location of larger shrubs. If a significant precipitation event should occur over a burned location on the NNSS, it is highly probable that runoff will produce sheet erosion and sediment loss via rills or gullies. The amount of runoff and erosion will be correlated to the amount and intensity of the precipitation event, soil physical properties and the slope of the burned area. As discussed in the literature review, despite similar enrichment 


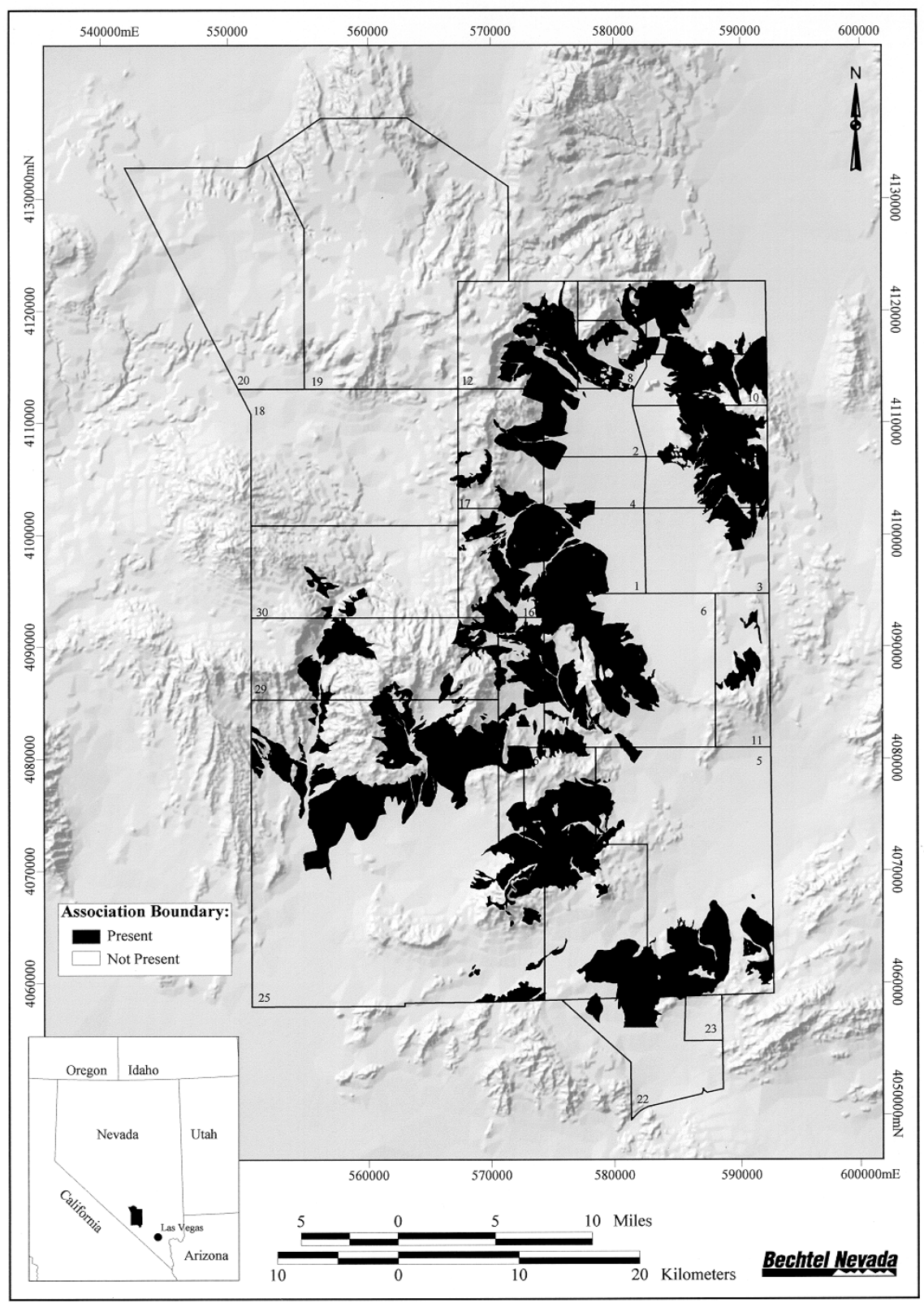

Figure 3. Distribution of Coleogyne ramosissima - Ephedra nevadensis shrubland on the NNSS; Figure 4-12 from Ostler et al., 2000; excerpted with author permission.

ratios ${ }^{6}$ between burned and unburned sites, both the amount of runoff and transport of radionuclide contaminants from burned sites are significantly greater than that of unburned sites; 22 times greater at WIPP and 4 times greater at RFETS (Johansen et al., 2001). It can therefore be anticipated that radionuclide contaminated sites that burn on the NNSS will also experience runoff events that will transport more radionuclide contaminated particles than runoff from unburned sites.

\footnotetext{
${ }^{6}$ higher radionuclide concentrations in eroded sediment in comparison to parent soil
} 


\section{Potential NNSS Fire Impacts}

These same set of fire impacts mentioned above also make surface soils of burned sites more prone to wind erosion. Ravi et al. (2006) found that hydrophobicity reduces the wind threshold velocity for particle suspension. Therefore, when wind speed exceeds the threshold velocity soil particles become suspended and are transported away from burned sites. In a comparison of similar burned and unburned semiarid shrubland sites, Whicker et al. (2002) found that although particle suspension occurred at both sites, loss of sediment only occurred at the burned site (with significantly more loss in under-canopy locations than interspaces) and deposition occurred in the under-canopy locations of the unburned site. Burned sites on the NNSS are also susceptible to wind erosion and wind-borne transport of contaminated particles beyond the boundaries of the radiologically controlled areas. Wind erosion of plutonium contaminated particles was documented for RFETS (Sehmel et al., 1978). Both respirable and non-respirable ${ }^{238} \mathrm{Pu}$ and ${ }^{239} \mathrm{Pu}$ were documented at this site. The enrichment ratio for windblown particles varied from none to two times that of the parent soil. However, the concentrations measured for this study were significantly below the maximum permissible air concentrations. These results are similar to those for a study performed $>30 \mathrm{~km}$ from Chernobyl, where the authors determined that exposures for firefighters spending 1 hour at the site received inhalation doses that were 1 percent of total annual doses (Kashparov et al., 2000). It was noted that if fire occurred in an area (within $30 \mathrm{~km}, 18.6$ miles, of the Chernobyl plant) where alpha particles are present, that firefighters would receive a significantly increased inhalation exposure.

Fire impacts on NNSS soil chemical properties will primarily result in a loss of OM and patchy enhancement of plant available $\mathrm{N}$. Enhancement of $\mathrm{N}$ has the potential to positively influence vegetative recovery of a burned site. Because the Mojave Desert, and the NNSS in particular, is generally sparsely vegetated, the duration of fires are typically not sufficient to result in enough soil heating for nutrient volatilization. Fires in the Mojave Desert do produce spatially heterogeneous, short-term pulses of $\mathrm{N}$ that may enhance seedling establishment in under canopy locations (Esque et al., 2010). However, these spatially heterogeneous increases in plant available $\mathrm{N}$ decline fairly quickly after fire events and if a rain event does not occur within a few months post-fire, germination will not take place in time for seedlings to benefit from the $\mathrm{N}$ pulse. The potential for fire to enhance germination and seedling recruitment of NNSS burned sites is therefore not probable given the highly variable timing and infrequent precipitation occurring in this region. As already documented on the NNSS (Hansen and Ostler, 2004) and at other Mojave Desert locations (Callison et al., 1985; Brooks, 1999; Brooks and Matchett, 2003; Abella, 2009) early post-fire vegetation recovery is dominated by annual forbs and grasses and particularly by invasive grasses and forbs, which result in the potential for increased fire frequency at these locations. Perennials and woody shrubs take up to decades to re-establish in burned areas and may never return the pre-fire species composition, particularly for blackbrush communities (Callison et al., 1985).

In summary, wildland fire on the NNSS will alter soil properties that significantly increase water and wind erosion of surface soils and any radionuclide contaminants present. Depending on distance and direction, transport of radionuclide particles may result in an increased human health risk. The post-fire increase in annual forbs and grasses increases the risk of more frequent fire occurrence because annual plants senesce and die prior to the onset of the monsoon season when lightning strikes serve as an ignition source for the dry plant biomass. 


\section{REFERENCES}

Abella, S.R., 2009. Post-fire recovery in the Mojave and Sonoran Deserts of western North America. Journal of Arid Environments, 73:699-707.

Anspaugh, L.R., J.H. Shinn, P.L. Phelps, and N.C. Kennedy, 1975. Resuspension and redistribution of plutonium in soils. Health Physics, 29:571-582.

Belnap, J., B. Büdel, and O.L. Lange, 2003. Biological soil crusts: Characteristics and distribution. In: Belnap, J. and O.L. Lange, Editors. Biological Soil Crusts: Structure, Function, and Management. Ecological Studies Series 150, Second Edition. SpringerVerlag, Berlin, pp.3-30.

Belnap, J. and D. Eldridge, 2003. Disturbance and recovery of biological soil crusts. In: Belnap, J. and O.L. Lange, Editors. Biological Soil Crusts: Structure, Function, and Management. Ecological Studies Series 150, Ecological Studies Series 150, Second Edition.Berlin, pp.363-383.

Belnap, J., S. L. Phillips, and S. D. Smith, 2007. Dynamics of cover, UV-protective pigments, and quantum yield in biological soil crust communities of an undisturbed Mojave Desert shrubland. Flora, 202:675-686.

Blank, R.R., F. Allen, and J.A. Young, 1994. Extractable anions in soils following wildfire in a sagebrush-grass community. Soil Science Society of America Journal, 58:564-570.

Blank, R.R., F.L. Allen, and J.A. Young, 1996. Influence of simulated burning of soil litter from low sagebrush, squirreltail, cheatgrass, and medusahead on water-soluble anions and cations. International Journal of Wildland Fire, 6(3):137-143.

Brooks, M.L., 1999. Alien annual grasses and fire in the Mojave Desert. Madroño, 46, 1316.

Brooks, M.L., 2002. Peak fire temperatures and effects on annual plants in the Mojave Desert. Ecological Applications, 12(4):1088-1102.

Brooks, M.L. and K.H. Berry, 2006. Dominance and environmental correlates of alien annual plants in the Mojave Desert, USA. Journal of Arid Environments, 67:100-124.

Brooks, M.L. and J.R. Matchett, 2003. Plant community patterns in unburned and burned Blackbrush (Coleogyne ramosissima Torr.) shrublands in the Mojave Desert. Western North American Naturalist, 63:283-298.

Brooks, M.L. and J.R. Matchett, 2006. Spatial and temporal patterns of wildfires in the Mojave Desert, 1980-2004. Journal of Arid Environments, 67:148-164.

Brown, D.E. and R.A. Minnich, 1986. Fire and changes in creosote bush scrub of the western Sonoran Desert, California (USA). American Midland Naturalist, 116, 411422.

Callison, J., J.D. Brotherson, and J.E. Bowns, 1985. The effects of fire on the blackbrush (Coleogyne ramosissima) community of southwestern Utah. Journal of Range Management, 38:535-538.

Campbell, G.S., J.D. Jungbauer Jr., W.R. Bidlake, and R.D. Hungerford, 1994. Predicting the effect of temperature on soil thermal conductivity. Soil Science, 158(5):307-313. 
Campbell, G.S., J.D. Jungbauer Jr., K.L. Bristow, and R.D. Hungerford, 1995. Soil temperature and water content beneath a surface fire. Soil Science, 159(6):363-374.

DeBano, L.F., 1990. Effects of Fire on the Soil Resource in Arizona Chaparral. In: Krammes, J. S., technical coordinator. Effects of Fire Management of Southwestern Natural Resources. United States Department of Agriculture, Forest Service, General Technical Report RM-191, pp. 65-77.

DeBano, L.F., 1991. The Effect of Fire on Soil Properties. In: Harvey, A.C. and L.F. Neuenschwander, compilers. Proceedings-Management and Productivity of WesternMontane Forest Soils. United States Department of Agriculture, Forest Service, General Technical Report INT-280, pp. 151-156.

DeBano, L.F., 2000. The role of fire and soil heating on water repellency in wildland environments: a review. Journal of Hydrology, 231-232:195-206.

DeBano, L.F. and C.E. Conrad, 1978. The effect of fire on nutrients in a chaparral ecosystem. Ecology, 59(3):489-497.

DeBano L.F., P.H. Dunn, and C.E. Conrad, 1977. Fire's Effect on Physical and Chemical Properties of Chaparral Soil. In Mooney, H.A. and C.E. Conrad, Editors. Proceedings of the Symposium on the Environmental Consequences of Fire and Fuel Management in Mediterranean Ecosystems. United States Department of Agriculture, Forest Service, General Technical Report WO-3, pp. 65-74.

DeBano, L.F. and J.S. Krammes, 1966. Water repellent soils and their relation to wildfire temperatures. International Association of Hydrological Sciences, 2:14-19.

DeBano, L.F., D.G. Neary, and P.F. Ffolliott, 1998. Fire's Effects on Ecosystems, John Wiley \& Sons, Inc., New York, NY, p. 333.

DeBano, L.F., R.M. Rice, and C.E. Conrad, 1979. Soil heating in Chaparral fires: effects on soil properties, plant nutrients, erosion and runoff. United States Department of Agriculture, Forest Service, Research Paper PSW-145, p. 27.

DeBano, L.F., S.M. Savage, and D.A. Hamilton, 1976. The transfer of heat and hydrophobic substances during burning. Soil Science Society of America Proceedings, 40(5):779782.

DeFalco L.A., T.C. Esque Todd, S.J. Scoles-Sciulla and J. Rodgers, 2010. Desert wildfire and severe drought diminish survivorship of the long-lived Joshua Tree (Yucca brevifolia; Agavaceae). American Journal of Botany, 97(2):243-250.

Dunn, P.J. and L.F. DeBano, 1977. Fire's Effect on Biological and Chemical Properties of Chaparral Soils. In: Mooney, H. A., and C. E. Conrad, Editors. Proceedings of the Symposium on the Environmental Consequences of Fire and Fuel Management in Mediterranean Ecosystems. United States Department of Agriculture, Forest Service, General Technical Report WO-3, pp. 75-84.

Dunn, P. H., S. C. Barro, and M. Path, 1985. Soil moisture affects survival of microorganisms in heated chaparral fire. Soil Biology and Biochemistry, 17:143-148. 
Eldridge, D.J. and R.A. Bradstock, 1994. The effect of time since fire on the cover and composition of cryptogamic soil crusts on Eucalyptus shrubland soil. Cunninghamia, 3:521-527.

Erickson, H. and R. White, 2008. Soils Under Fire: Soils Research and the Joint Fire Science Program. General Technical Report PNWGTR-759. Portland, OR: United States Department of Agriculture, Forest Service, Pacific Northwest Research Station, p. 17.

Esque, T.C., J.P. Kaye, S.E. Eckert, L.A. DeFalco, and C.R. Tracy, 2010. Short-term soil inorganic $\mathrm{N}$ pulse after experimental fire alters invasive and native annual plant production in a Mojave Desert Shrubland. Oecologia, 164:253-263.

Gabet, E.J., 2003. Post-fire thin debris flows: sediment transport and numerical modeling. Earth Surface Processes and Landforms 28:1341-1348.

Hand, J.L., S.A. Copeland, D.E. Day, A.M. Dillner, H. Indresand, W.C. Malm, C.E. McDade, C.T. Moore Jr., M.L. Pitchford, B.A. Schichtel, and J.G. Watson, 2011. Spatial and Seasonal Patterns and Temporal Variability of Haze and its Constituents in the United States Report V. Cooperative Institute for Research in the Atmosphere, June 2011; ISSN 0737-5352-87.

Hansen, D. J., D. C. Anderson, D. B. Hall, D. Greger, and W. K. Ostler, 2011. Ecological Monitoring and Compliance Program 2010 Report. DOE/NV/25946-1202National Security Technologies, LLC, Ecological Services, Las Vegas, NV. July 2011.

Hansen, D. J., and W. K. Ostler, 2004. A Survey of Vegetation and Wildland Fires on the Nevada Test Site. DOE/NV/11718-981. Bechtel Nevada, Ecological Services, Las Vegas, NV.

Hare, R.C., 1961. Heat Effects on Living Plants. United States Department of Agriculture, Forest Service, Occasional Paper 183. Southern Forest Experiment Station, New Orleans, Louisiana.

Hosking, J.S., 1938. The ignition at low temperatures of the organic matter in soils. Journal of Agricultural Science, 28:393-400.

Hubbert, K.R., H.K. Preisler, P.M. Wohlgemuth, R.C. Graham, and M.G. Narog, 2006. Prescribed burning effects on soil physical properties and soil water repellency in a steep chaparral watershed, southern California, USA. Geoderma, 130:284-298.

Hungerford, R.D., M.G. Harrington, W.H. Frandsen, K.C. Ryan, and G.J. Niehoff, 1991. The Influence of Rire on Factors that Affect Site Productivity. In: Harvey AC, Nuenschwander LF (comps.). Proceedings, Management and Productivity of Western Montane Forest Soils. Gen. Tech. Rep. INT-280. Ogden, UT: U.S. Department of Agriculture, Forest Service, Intermountain Forest and Range Experiment Station. pp. 32-50.

Hunter, R., 1991. Bromus invasions on the Nevada Test Site: present status of B. Rubens and B. tectorum with notes on their relationship to disturbance and altitude. Great Basin Naturalist, 51:176-182. 
Jaffe, D., W. Hafner, D. Chand, A. Westerling, and D. Apracklen, 2008. Interannual variations in PM2.5 due to wildfires in the western United States. Environmental Science \& Technology, 42:2812-2818.

Johansen, J.R., 2003. Impacts of Fire on Biological Soil Crusts. In: Belnap, J. and O.L. Lange, editors. Biological Soil Crusts: Structure, Function, and Management. Ecological Studies Series 150, Second Edition. Springer-Verlag, Berlin.

Johansen, M.P., T.E. Hakonson, F.W. Whicker, J.R. Simanton, and J.J. Stone, 2001. Hydrologic response and radionuclide transport following fire at semiarid sites. Journal of Environmental Quality, 30:2010-2017.

Johnson, S.R., D.D. Breshears, and T.B. Kirchner, 2000. Multi-path-way, multi-site contaminant transport: Assessing vertical migration, wind erosion, and water erosion at semiarid DOE sites. Proceedings Abstract in Health Physics, 78(6):S159.

Kashparov, V.A., S.M. Lundin, A.M. Kadygrib, V.P. Protsak, S.E. Levtchuk, V.I. Yoschenko, V.A. Kashpur, and N.M. Talerko, 2000. Forest fires in the territory contaminated as a result of the Chernobyl accident: Radioactive aerosol resuspension and exposure of fire-fighters. Journal of Environmental Radioactivity, 51:281-298.

Klopatek, C.C., L.F. DeBano, and J.M. Klopatek, 1988. Effects of simulated fire on vesicular-arbuscular mycorrhiazae in pinyon-juniper woodland soil. Plant and Soil, 109:245-249.

Klopatek, C.C., C. Friese, M.F. Allen, and J.M. Klopatek, 1993. Comparisons of laboratory and field burning experiments on mycorrhizal distribution, density and diversity. Journal of Society of American Foresters, (Twelfth International Conference on Fire and Forest Mineralogy, Special. Issue), 94: 762-776.

Knapp, P.A., 1998. Spatio-temporal patterns of large grassland fires in the Intermountain West, U.S.A. Global Ecology and Biogeography Letters, 7:259-272.

Knoepp, J.D., L.F. DeBano, and D.G. Neary, 2005 (Revised 2008). Chapter 3: Soil Chemistry. In: D.G. Neary, K.C. Ryan, L.F. DeBano, Editors. Wildland Fire in Ecosystems: Effects of Fire on Soils and Water. General Technical Report RMRSGTR-42-vol.4. Ogden, UT: United States Department of Agriculture, Forest Service, Rocky Mountain Research Station. p. 250.

Loik, M.E., C.D. St. Onge, and J. Rogers, 2000. Post-fire recruitment of Yucca brevifolia and Yucca schidigera in Joshua Tree National Park, California. In Keeley, J. E, M. Baer-Keeley, and C. J. Fotheringham, Editors. Second Interface Between Ecology and Land Development in California, pp. 79-85. Open-File Report 00-62, United States Geological Survey, Sacramento, California, USA.

Lyon, J.L., H.S. Crawford, E. Czuhai, R.L. Fredriksen, R.F. Harlow, L.J. Metz, and H.A. Pearson, 1978. Effects of Fire on Fauna: A State-of-Knowledge Review. United States Department of Agriculture, Forest Service, General Technical Report WO-6.

Maim, W.C., B.A. Schichtel, M.L. Pitchford, L.L. Ashbaugh, and R.A. Eldred, 2004. Spatial and monthly trends in speciated fine particle concentration in the United States. Journal of Geophysical Research 109, p. 22, doi:10.1029/2003JD003739. 
Martin, R.E., R.L. Miller, and C.T. Cushwa, 1975. Germination response of legume seeds subjected to moist and dry heat. Ecology 56:1441-1445.

Moody, J.A., D.A. Martin, and S.H. Cannon, 2008. Post-wildfire erosion response in two geologic terrains in the western USA. Geomorphology 95:103-118.

National Wildfire Coordinating Group, 2001. Fire Effects Guide. Available online: http://www.nwcg.gov/pms/RxFire/FEG.pdf. p. 313.

Neary, D.G., C.C. Klopatek, L.F. DeBano, and P.F. Ffolliott, 1999. Fire effects on belowground sustainability: a review and synthesis. Forest Ecology and Management 122:51-71.

Neary, D.G., K.C. Ryan, and L.F. DeBano, Editors, 2008. Wildland Fire in Ecosystems: Effects of Fire on Soils and Water. General Technical Report RMRS-GTR-42-vol.4. Ogden, UT: United States Department of Agriculture, Forest Service, Rocky Mountain Research Station. p. 250.

Ostler, W.K.; Hansen, D.J.; Anderson, D.C.; Hall, D.B. 2000. Classification of vegetation on the Nevada Test Site. December 6, 2000. DOE/NV/11718-477. Las Vegas, NV: U.S. Department of Energy, Nevada Operations Office.

Park, R.J., D.J. Jacob, and J.A. Logan, 2007. Fire and biofuel contributions to annual mean aerosol mass concentrations in the United States. Atmospheric Environment 41:73897400.

Pierson, F.B., D.H. Carlson, and K.E. Spaeth, 2002. Impacts of wildfire on soil hydrological properties of steep sagebrush-steppe rangeland. International Journal of Wildland Fire 11:145-151.

Precht, J., J. Chrisphersen, H. Hensel, and W. Larcher, 1973. Temperature and Life. Springer-Verlag, New York.

Raison, R.J., P.K. Khanna, and P.V. Woods, 1985. Mechanisms of element transfer to the atmosphere during vegetation fires. Canadian Journal of Forest Research 15:132-140.

Ravi, S., P. D'Odorico, B.E. Herbert, T.M. Zobeck, and T.M. Over, 2006. Enhancement of wind erosion by fire-induced water repellency. Water Resources Research 42 (11), W11422. doi:10.1029/2006WR004895.

Ravi, S., P. D’Odorico, T.M. Zobeck, and T.M. Over, 2009. The effect of fire-induced soil hydrophobicity on wind erosion in a semiarid grassland: experimental observations and theoretical framework. Geomorphology 105:80-86.

Robichaud, P.R., W.J. Elliot, F.B. Pierson, D.E. Hall, and C.A. Moffet, 2006. Erosion Risk Management Tool (ERMiT). Version 2006.01.18. http://forest.moscowfsl.wsu.edu/fswepp/. (December 2007).

Robichaud, P.R., W.J. Elliot, F.B. Pierson, D.E. Hall, and C.A. Moffet, 2007a. Erosion Risk Management Tool (ERMiT) user manual (version 2006.01.18). General Technical Report RMRS-GTR-188. Fort Collins, CO: United States Department of Agriculture, Forest Service, Rocky Mountain Research Station, p. 24. 
Robichaud, P.R., W.J. Elliot, F.B. Pierson, D.E. Hall, and C.A. Moffet, 2007b. Predicting postfire erosion and mitigation effectiveness with a Web-based probabilistic erosion model. Catena, 71:229-241.

Robinson, M.S., J. Chavez, and S. Velazquez, 2004. Chemical speciation of PM2.5 collected during prescribed fires of the Coconino National Forest near Flagstaff, Arizona. Journal of Air \& Waste Management Association 54:1112-1123.

Rogers, G.F. and J. Steele, 1980. Sonoran Desert fire ecology p. 15-19. In: Proceedings of the fire history workshop. United States Forest Service General Technical Report RM81. Fort Collins, Colorado, p. 142.

Ryan, K.C. 2002. Dynamic interactions between forest structure and fire behavior in Boreal ecosystems. Silva Fennica 36(1):13-39.

Sandberg, D.V. and R.E. Martin, 1975. Particle sizes in slash fire smoke. United States Department of Agriculture, Forest Service Research Paper PNW-199, p. 7.

Schlesinger,W.H., J.A. Raikes, A.E. Hartley, and A.F. Cross, 1996. On the spatial pattern of soil nutrients in desert ecosystems. Ecology, 77:364-374.

Seager, R., M.F. Ting, I.M. Held, Y. Kushnir, J. LuJ, G. Vecchi, H-P, Huang, N. Harnik, A. Leetmaa, N-C. Lau, C. Li, J. Velez, and N. Naik, 2007. Model projections of an imminent transition to a more arid climate in Southwestern North America. Science 316:1181-1184.

Sehmel, G.A., 1978. Plutonium concentrations in airborne soil at Rocky Flats and Hanford determined during resuspension experiments. PNL-SA-6720. Pacific Northwest Laboratories, Richland, WA, p. 23.

Smith, S.D., T.E. Huxman, S.F. Zitzer, T.N. Charlet, D.C. Housman, J.S. Coleman, L.K. Fenstermaker, J.R. Seemann, R.S. Nowak, 2000. Elevated $\mathrm{CO}_{2}$ increases productivity and invasive species success in an arid ecosystem. Nature 408:79-82.

Smith, S.D., B.R. Strain, T.D. Sharkey, 1987. Effects of CO2 enrichment on four Great Basin grasses. Functional Ecology, 1:139-143.

Titus, J. H., R. S. Nowak, and S. D. Smith, 2002. Soil resource heterogeneity in the Mojave Desert. Journal of Arid Environments, 52:269-292.

Welling, M., M. Singer, and P. Dunn, 1984. Effects of fire on shrubland soils. In: DeVries, J.J., Editor, Shrublands in California: Literature Review and Research Needed for Management. Water Resources Center Report, University of California, Davis; ISSN 0575-4941.

Wells, W. G., 1987. The effects of fire on the generation of debris flows in southern California. Reviews in Engineering Geology, 7:105-114.

Westerling, A.L., H.G. Hidalgo, D.R. Cayan, and T.W. Swetnam, 2006. Warming and earlier spring increase western United States forest wildfire activity. Science 313:940943. 
Whicker, J.J., D.D. Breshears, P.T. Wasiolek, T.B. Kirchner, R.A. Tavani, D.A. Schoep, and J.C. Rodgers, 2002. Temporal and spatial variation of episodic wind erosion in unburned and burned semiarid shrubland. Journal of Environmental Quality 31:599_ 612.

White, E.M., W.W. Thompson, and F.R. Gartner, 1973. Heat effects on nutrient release from soils under Ponderosa pine. Journal of Range Management 26(1):22-24. 